\title{
FGFR3-TACC3 fusion in solid tumors: mini review
}

Review

\author{
Ricardo Costa ${ }^{1,2}$, Benedito A. Carneiro, ${ }^{1,2}$, Timothy Taxter ${ }^{1,3}$, Fabio A. Tavora ${ }^{4}$, \\ Aparna Kalyan ${ }^{1,2}$, Sachin A. Pai ${ }^{1,2}$, Young Kwang Chae ${ }^{1,2}$ and Francis J. Giles ${ }^{1,2}$ \\ ${ }^{1}$ Developmental Therapeutics Program, Division of Hematology and Oncology, Feinberg School of Medicine, Northwestern \\ University, Chicago, Illinois, USA \\ ${ }^{2}$ Robert H. Lurie Comprehensive Cancer Center of Northwestern University, Chicago, Illinois, USA \\ ${ }^{3}$ Department of Pathology, Feinberg School of Medicine, Northwestern University, Chicago, Illinois, USA \\ ${ }^{4}$ Department of Pathology, Messejana Heart and Lung Hospital, Fortaleza, Brazil \\ Correspondence to: Ricardo Costa, email: ricardo.costa@northwestern.edu \\ Keywords: FGFR3-TACC3 fusion, non-small cell lung cancer, phosphatidylinositol 3-Kinase (PI3K), aneuploidy, glioblastoma multi- \\ forme \\ Received: April 30, $2016 \quad$ Accepted: June 09, $2016 \quad$ Published: July 07, 2016
}

\section{ABSTRACT}

Fibroblast growth factor receptors (FGFR) are transmembrane kinase proteins with growing importance in cancer biology given the frequency of molecular alterations and vast interface with multiple other signaling pathways. Furthermore, numerous FGFR inhibitors in clinical development demonstrate the expanding therapeutic relevance of this pathway. Indeed, results from early phase clinical trials already indicate that a subset of patients with advanced tumors derive benefit from FGFR targeted therapies. FGFR gene aberrations and FGFR gene rearrangements are relatively rare in solid malignancies. The recently described FGFR3-TACC3 fusion protein has a constitutively active tyrosine kinase domain and promotes aneuploidy. We summarize the prevalence data on FGFR3-TACC3 fusions among different histological tumor types and the preliminary evidence that this rearrangement represents a targetable molecular aberration in some patients with solid tumors.

\section{INTRODUCTION}

The growing knowledge base of tumor genomics has led to never seen advances in the field of medical oncology. [1] The evolving molecularly targeted treatments of late-stage melanoma, gastro-intestinal stromal tumors, and non-small-cell lung cancer (NSCLC) exemplify these advances. [2-4]

The fibroblast growth factor receptor (FGFR) family consists of four subtypes of transmembrane tyrosine kinase receptors that play an important role in cell growth, differentiation and angiogenesis via binding of up to 22 known different FGF family ligands. [5] Upon FGFR activation through dimerization of receptor monomers and transphosphorylation of kinase domain loop tyrosine residues cytoplasmatic downstream molecules contribute to carcinogenic events mediated by PI3K/AKT, STAT and RAS/MAPK pathways (Figure 1A). [5, 6]

Anomalous signaling through FGFR can occur through overexpression of receptors, activating mutations, gene amplification, or by FGFR-containing translocations in wide array of solid tumors as discussed below. Most importantly, these aberrations can represent important therapeutic targets in solid tumors and have supported the clinical development of several FGFR inhibitors and anti-FGFR drug conjugate (ADC) antibodies (Table 3-9). Herein we review the current literature and describe the cancer pathobiology, the prevalence, the pre-clinical, and the clinical data supporting drug development targeting the recently described FGFR3-TACC3 fusion.

\section{FGFR ABERRATIONS}

$F G F R$ alterations relatively rare and were present in $\sim 7 \%$ of a cohort of 4853 tumor samples including 47 different histological types. [7] When limiting to histologies with at least 75 samples analyzed, the frequencies of FGFR aberrations were higher among 
Table 1: Co-existing genomic aberrations among 14 FGFR3-TACC3 fusion cases.[7]

\begin{tabular}{|c|c|c|c|c|c|c|c|c|}
\hline Histology & Cell cycle & PI3Kinase & TP53 & DNA repair & \begin{tabular}{|l|} 
Transcription/ \\
Histone \\
methylation \\
\end{tabular} & \begin{tabular}{|l|}
$\begin{array}{l}\text { Growth } \\
\text { factor } \\
\text { receptor }\end{array}$ \\
\end{tabular} & $\begin{array}{l}\text { RAS/ } \\
\text { RAF/ } \\
\text { MAPK } \\
\end{array}$ & Other \\
\hline CUP & $\begin{array}{l}C D K 4- \\
\text { amplification }\end{array}$ & & & & & & & $\begin{array}{l}\text { MDM2-amp } \\
\text { ARID1A-A343 } \\
\text { A348>A }\end{array}$ \\
\hline Cervical cancer & & PIK3CA-E545K & & & & & & \\
\hline Cervical cancer & & & TP53-R248Q & $A T M-V 2115 f s * 5$ & & & & \\
\hline $\begin{array}{l}\text { Endometrial } \\
\text { adenocarcinoma }\end{array}$ & & PIK3CA-E365K & TP53-W91* & & & FLT3-E978* & & $\begin{array}{l}K M T 2 A- \\
\text { complex } \\
\text { rearrange }\end{array}$ \\
\hline $\begin{array}{l}\text { Gallbladder } \\
\text { carcinoma }\end{array}$ & $\begin{array}{l}C C N E 1- \\
\text { amplification }\end{array}$ & & TP53-C141* & & $\begin{array}{l}Y Y C- \\
\text { amplification }\end{array}$ & & & $\begin{array}{l}\text { MCL1- } \\
\text { amplification }\end{array}$ \\
\hline Glioma & & & TP53-E258K & & & & & \begin{tabular}{|l|} 
NF1 \\
Y2285fs*5, \\
Q270* \\
MCL1- \\
amplification \\
NFKBIA- \\
amplification \\
PTPN11-E76K
\end{tabular} \\
\hline Glioma & $\begin{array}{l}C D K 4- \\
\text { amplification }\end{array}$ & $\begin{array}{l}\text { PTEN-splice site } \\
209+1 \text { delGT }\end{array}$ & & & & & & $\begin{array}{l}\text { MDM2- } \\
\text { amplification }\end{array}$ \\
\hline $\begin{array}{l}\text { NSCLC } \\
\text { Not specified }\end{array}$ & $C D K N 2 A$-loss & & & & & & & $\begin{array}{l}\text { MDM2- } \\
\text { amplification }\end{array}$ \\
\hline $\begin{array}{l}\text { Pancreatic exocrine } \\
\text { carcinoma }\end{array}$ & & & TP53-I195F & $A T M-R 805^{*}$ & $\begin{array}{l}\text { MYC- } \\
\text { amplification }\end{array}$ & & & SMAD4-loss \\
\hline Renal cell carcinoma & $\begin{array}{l}C D K N 2 A / B- \\
\text { loss }\end{array}$ & & TP53-R196* & & $\begin{array}{l}\text { MYC- } \\
\text { amplification }\end{array}$ & & & \begin{tabular}{|l|} 
TOP1- \\
amplification \\
SRC- \\
amplification \\
AURKA- \\
amplification \\
VHL-P25L \\
\end{tabular} \\
\hline $\begin{array}{l}\text { Urothelial } \\
\text { carcinoma }\end{array}$ & $\begin{array}{l}\text { CCND1- } \\
\text { amplification }\end{array}$ & PIK3CA-H1047R & TP53-R280T & & & & & \\
\hline $\begin{array}{l}\text { Urothelial } \\
\text { carcinoma }\end{array}$ & & & $T P 53-K 132 N$ & & & & & $\begin{array}{l}J U N- \\
\text { amplification } \\
\text { IRS2- } \\
\text { amplification } \\
\text { MCL1- } \\
\text { amplification }\end{array}$ \\
\hline $\begin{array}{l}\text { Urothelial } \\
\text { carcinoma }\end{array}$ & $\begin{array}{l}\text { CCND1- } \\
\text { amplification } \\
C D K N 2 A / B- \\
\text { loss } \\
\end{array}$ & PIK3R2-E543* & & & & $\begin{array}{l}E R B B 2 \\
\text { amplification }\end{array}$ & $\begin{array}{l}\text { MAP3K1- } \\
\text { truncation, } \\
\text { exon } 15\end{array}$ & $\begin{array}{l}\text { MDM2- } \\
\text { amplification } \\
\text { NF1-I1351M }\end{array}$ \\
\hline $\begin{array}{l}\text { Urothelial } \\
\text { carcinoma }\end{array}$ & $\begin{array}{l}C D K N 2 A / B- \\
\text { loss }\end{array}$ & & & & & & & $\begin{array}{l}\text { IRS2- } \\
\text { amplification } \\
M D M 2- \\
\text { amplification }\end{array}$ \\
\hline
\end{tabular}

Abbreviations: Non-small cell lung cancer (NSCLC), carcinoma of unknown primary (CUP), mouse double minute 2 homolog (MDM2), cyclin E1 gene (CCNE1), cyclin D1 gene(CCND1), cyclin dependent kinase(CDK), cyclin dependent kinase inhibitor (CDKN), phosphatidylinositol 3-Kinase (PI3K), Erb-B2 receptor tyrosine kinase 2 (ERBB2), tumor protein P53(TP53), phosphatase and tensin homolog(PTEN), V-Myc Avian Myelocytomatosis viral oncogene homolog (MYC), ataxia telangiectasia mutated(ATM), mitogen-activated protein kinase 1 (MAP3K1), AT rich interactive domain 1A (ARID1A), lysine (K)-specific methyltransferase 2A(KMT2A), myeloid cell leukemia 1(MCL1), neurofibromin 1(NF1), Nuclear Factor Of Kappa Light Polypeptide Gene Enhancer In B-Cells Inhibitor, alpha (NFKBIA), protein tyrosine phosphatase, non-Receptor Type 11(PTPN11), SMAD family member 4(SMAD4), topoisomerase (DNA) I(TOP1), SRC proto-oncogene(SRC), aurora kinase A(AURKA), von hippel-lindau tumor suppressor (VHL), Jun proto-oncogene(JUN), insulin receptor substrate 2(IRS2).

urothelial (31.7\%), breast (17.4\%), endometrial (11.3\%), and endometrial/ovarian carcinomas (8.1\%). [7] The majority of FGFR genomic alterations were FGFR amplifications and mutations (92\%).

Evidence from early phase clinical trials support that FGFR aberrations can represent targetable events in solid tumors. In a phase I trial, twenty one patients with refractory squamous non-small cell lung cancer (sqNSCLC) harboring FGFRI-amplification were treated with the small molecule FGFR inhibitor BGJ398 (100 or $125 \mathrm{mg}$ once daily in 28-day cycles). [8] Of 17 evaluable patients, 4 had radiologic tumor reduction and 3 had stable disease indicating that a subset of patients with FGFR pathway aberrations indeed benefits for FGFR targeted 
Table 2: Cross-sectional studies and case series reporting positive FGFR3-TACC3 fusions (excluding TCGA dataset samples)

\begin{tabular}{|c|c|c|c|c|c|c|}
\hline Authors & Tumor type & $\begin{array}{l}\text { Number } \\
\text { of cases } \\
\text { analyzed }\end{array}$ & \begin{tabular}{|l|}
$\begin{array}{l}\text { Number } \\
\text { of cases } \\
\text { harboring }\end{array}$ \\
$F G F R 3-$ \\
TACC3 \\
fusion \\
\end{tabular} & $\begin{array}{l}\text { FGFR3 } \\
\text { breakpoint }\end{array}$ & $T A C C 3$ breakpoint & Comments \\
\hline Helsten et al.[7] & Urothelial carcinoma & 126 & 4 & NR & NR & $\begin{array}{l}\text { Organ site was not } \\
\text { specified }\end{array}$ \\
\hline Williams et al.[15] & Bladder carcinoma & 32 & 2 & Exon 18 & Exon 13 & \\
\hline Singh et a.l[13] & GBM & 97 & 2 & Exon 17 & Intron 7 & \\
\hline Di Stefano et a.l[23] & Gliomas & 795 & 20 & Exon 17,18 & $\begin{array}{l}\text { Exon } 4,5,6,8,10, \\
11\end{array}$ & $\begin{array}{l}17 \text { patients had GBM } \\
\text { and } 3 \text { patients grade III } \\
\text { or II gliomas }\end{array}$ \\
\hline Parker et al. [22] & GBM & 48 & 4 & -- & -- & \\
\hline Bao Z. et al [27] & GBM & 59 & 3 & Exon 17 & Exons $8,10,11$ & \\
\hline Helsten et al .[7] & $\begin{array}{|ll|}\text { NSCLC } & \\
\text { (subtype } & \text { not } \\
\text { specified) } & \\
\end{array}$ & 675 & 1 & NR & NR & $\begin{array}{l}\text { NSCLC subtype was not } \\
\text { specified }\end{array}$ \\
\hline Capelletti et al.[30] & $\begin{array}{l}\begin{array}{l}\text { Adenocarcinoma of } \\
\text { the lung }\end{array} \\
\end{array}$ & 576 & 3 & Exon 17 & Exon 4, 8, 11 & \\
\hline Wang et al. [31] & $\begin{array}{l}\text { NSCLC } \\
(6 \text { adenocarcinomas } \\
9 \text { sqNSCLC) }\end{array}$ & 1328 & 15 & Exon 17,18 & Exon $5,8,10,11$ & \begin{tabular}{|lr}
6 & cases of \\
adenocarcinoma and 9 \\
cases of SCC; FGFR3- \\
TACC3 correlated \\
independently with \\
tumor size $>3 \mathrm{~cm}$ \\
\end{tabular} \\
\hline Kim et al.[32] & sqNSCLC & 104 & 2 & Exon 17, 18 & Exon 8,9 & $\begin{array}{l}\text { Author also found } 4 \\
\text { more cases at the TGCA } \\
\text { dataset }\end{array}$ \\
\hline Majewski et al.[33] & sqNSCLC & 95 & 2 & Exon 18 & Exon 10 & $\begin{array}{l}\text { Fusion was identified in } \\
2 \text { SCC cases }\end{array}$ \\
\hline Carneiro et al.[36] & $\begin{array}{l}\text { Cervical cancer: SSC } \\
\text { and adenosquamous } \\
\text { cell carcinoma, }\end{array}$ & -- & 3 & Intron 17,18 & Intron 7,10 & \\
\hline Xiang et al. [37] & $\begin{array}{l}\text { Cervical } \\
\text { cancer: SCC, } \\
\text { adenocarcinoma, } \\
\text { adenosquamous, } \\
\text { small cell carcinoma } \\
\end{array}$ & 285 & 11 & -- & -- & All early stage tumors \\
\hline Helsten et al. [7] & $\begin{array}{l}\text { Cervical } \\
\text { adenocarcinoma and } \\
\text { cervical carcinoma } \\
\text { not specified }\end{array}$ & 48 & 2 & Intron 17 & Intron 7 & $\begin{array}{l}\text { Fusion reported for } \\
\text { carcinoma NOS }\end{array}$ \\
\hline Helsten et al. [7] & \begin{tabular}{|l} 
Carcinoma of \\
unknown primary
\end{tabular} & 267 & 1 & NR & NR & \\
\hline Helsten et al. [7] & \begin{tabular}{|l|} 
Endometrial \\
Carcinoma
\end{tabular} & 80 & 1 & NR & NR & \\
\hline Helsten et al.[7] & $\begin{array}{l}\text { Gallbladder } \\
\text { carcinoma }\end{array}$ & 47 & 1 & NR & NR & \\
\hline Helsten et al. [7] & Glioma & 144 & 1 & NR & NR & \\
\hline Helsten et al. [7] & \begin{tabular}{|l|}
$\begin{array}{l}\text { Pancreatic exocrine } \\
\text { tumor }\end{array}$ \\
\end{tabular} & 172 & 1 & Exon 18 & Intron 10 & \\
\hline Helsten et al. [7] & Renal cell carcinoma & 87 & 1 & NR & NR & \\
\hline Parish et al.[39] & Solid tumors & 391 & 1 & NR & NR & \\
\hline
\end{tabular}




\begin{tabular}{|c|c|c|c|c|}
\hline Drug & $\begin{array}{l}\text { Mechanism of } \\
\text { action }\end{array}$ & Phase & Study population & \begin{tabular}{|l} 
Clinicaltrials. \\
gov \\
Identification \\
\end{tabular} \\
\hline ARQ 087 & FGFR1-3 TKI & $1 / 2$ & \begin{tabular}{|l|} 
Solid tumors with FGFR genetic alterations, including \\
intrahepatic cholangiocarcinoma with $F G F R 2$ gene fusion
\end{tabular} & NCT01752920 \\
\hline AZD4547 & FGFR1-3 TKI & 2 & $\begin{array}{l}F G F R 1 \text { or } F G F R 2 \text { amplified breast, squamous lung and } \\
\text { stomach cancer }\end{array}$ & NCT01795768 \\
\hline AZD4547 & FGFR1-3 TKI & 1 & $\begin{array}{l}\text { In the dose expansion phase participant must have solid } \\
\text { tumors with } F G F R 1 \text { and/or } F G F R 2 \text { gene amplified sqNSCLC, } \\
F G F R 1 \text { gene low \& high amplified or gastric adenocarcinoma, } \\
\text { including the lower esophagus/gastro-esophageal junction, } \\
F G F R 2 \text { gene low \& high amplified }\end{array}$ & NCT00979134 \\
\hline AZD4547 & FGFR1-3 TKI & 2 & $\begin{array}{l}\text { Advanced Gastric Adenocarcinoma (Including } \\
\text { adenocarcinoma of the lower third of the esophagus or the } \\
\text { gastro-esophageal junction) with FGFR2 polysomy or gene } \\
\text { amplification. }\end{array}$ & NCT01457846 \\
\hline AZD4547 & FGFR1-3 TKI & $2 \mathrm{a}$ & $\begin{array}{l}\text { ER+ breast cancer patients With FGFR1 polysomy or gene } \\
\text { amplification who have progressed following treatment with } \\
\text { prior endocrine therapy }\end{array}$ & NCT01202591 \\
\hline AZD4547 & FGFR1-3 TKI & $2 \mathrm{a}$ & Refractory metastatic ER+ breast cancer & NCT01791985 \\
\hline AZD4547 & FGFR1-3 TKI & 1 & Japanese patients with advanced solid tumors & NCT01213160 \\
\hline BAY1163877 & FGFR1-3 TKI & 1 & $\begin{array}{l}\text { In the dose expansion cohort patient must have histological or } \\
\text { cytological sqNSCLC, lung adenocarcinoma, head and neck } \\
\text { cancer or bladder cancer }\end{array}$ & NCT01976741 \\
\hline BAY1187982 & \begin{tabular}{|l|}
$\begin{array}{l}\text { Anti-FGFR2 } \\
\text { antibody drug } \\
\text { conjugate }\end{array}$ \\
\end{tabular} & 1 & Advanced solid tumors known to express FGFR2 & NCT02368951 \\
\hline BAY1179470 & $\begin{array}{l}\text { Anti } \\
\text { antibody }\end{array}$ & 1 & $\begin{array}{l}\text { Refractory solid tumors with at least moderate FGFR2 } \\
\text { expression in the tumor tissue from archival samples is } \\
\text { confirmed }\end{array}$ & NCT01881217 \\
\hline BGJ398 & FGFR1-3 TKI & $2 \mathrm{a}$ & $\begin{array}{l}\text { FGFR1-3 translocated, mutated, or amplified squamous cell } \\
\text { carcinoma of the head and neck }\end{array}$ & NCT02706691 \\
\hline BGJ398 & FGFR1-3 TKI & 2 & \begin{tabular}{|l|} 
Solid tumor (except with a primary diagnosis of UC, \\
cholangiocarcinoma, endometrial cancer, and GBM) or \\
hematologic malignancies with $F G F R$ genetic alteration
\end{tabular} & NCT02160041 \\
\hline BGJ398 & FGFR1-3 TKI & 1 & $\begin{array}{l}\text { Advanced solid tumors with } F G F R 1 \text { or } F G F R 2 \text { amplification } \\
\text { or } F G F R 3 \text { mutation, for which no further effective standard } \\
\text { anticancer treatment exists or UC with } F G F R 3 \text { mutations or } \\
\text { gene fusions progressing after platinum-based chemotherapy } \\
\text { or intolerant to platinum therapy or for whom platinum is } \\
\text { contraindicated }\end{array}$ & NCT01004224 \\
\hline \begin{tabular}{|l|} 
BGJ398 \\
combined with \\
chemotherapy
\end{tabular} & FGFR1-3 TKI & $1 \mathrm{~b} / 2$ & Advanced and metastatic pancreatic cancer & NCT02575508 \\
\hline \multicolumn{5}{|c|}{$\begin{array}{l}\text { Abbreviations: Fibroblast growth factor (FGF), fibroblast growth factor receptor (FGFR), not reported (NR), estrogen } \\
\text { receptor positive (ER+), tyrosine kinase inhibitor (TKI), bacillus calmette-Guerin (BCG), small cell lung cancer (SCLC), } \\
\text { Non-small cell lung cancer (NSCLC), squamous non-small cell lung cancer (sqNSCLC), pilot study (PS), glioblastoma } \\
\text { multiforme (GBM), hepatocellular carcinoma (HCC), Malignant pleural mesothelioma (MPM), immunohistochemistry } \\
\text { (IHC), urothelial carcinoma (UC). www.clinicaltrials.gov accessed on April } 22^{\text {nd }} 2016\end{array}$} \\
\hline
\end{tabular}

therapy. In another phase I trial BGJ398 also showed evidence of clinical activity in patients with solid tumors harboring FGFR aberrations, including 4 of 5 patients with urothelial cell carcinomas (4 of which originated in the bladder) with $F G F R 3$-activating mutations. Additionally, two patients with FGFRl-amplified sqNSCLC achieved confirmed partial response. Tumor reductions were also observed in cholangiocarcinoma with an FGFR2 gene fusion, and FGFR1-amplified breast cancer. [9] In summary, given the rarity of $F G F R$ aberrations the preliminary evidence of antitumor activity of FGFR targeted therapies comes from subpopulations of small early phase clinical trials. A small number of partial responses to FGFR targeted therapies have been documented among patients with sqNSCLC harboring FGFR1 amplification (BGJ398), cholangiocarcinoma harboring FGFR2 translocations (BGJ398), glioblastoma positive for $F G F R 3$ translocation (JNJ-42756493), bladder 
cancer harboring FGFR3 mutations and translocations are sensitive to targeted therapies (JNJ-42756493 and BGJ398). [8-11]

\section{FGFR3-TACC3 TRANSLOCATION}

Fusions have been described in the FGFR13 genes with multiple partners (i.e., TACC1, TACC2, TACC3, BAIAP2L1, BICC1, NPM1, PPAPDC1A, $A F F 3, S L C 45 A 3$ and $A H C Y L 1)$ in a wide spectrum of tumors (i.e., cholangiocarcinoma, breast, and prostate cancer, sqNSCLC, gastric adenocarcinoma, colorectal adenocarcinoma, carcinoma of unknown primary and glioblastoma). [7, 12-15]

Other rare $F G F R$ fusions described included FGFR2-TACC3 (1), FGFR2-NPM1(3), FGFR2TACC2(2), FGFR2-BICC1(2), FGFR2-C10orf68(1), FGFR3-JAKMIP1(1), FGFR2-KIAA1598(1), FGFR2NCALD(1), FGFR2-NOL4(1), FGFR1-NTM(1), FGFR2PPAPDCA(1), FGFR3-TNIP2(1), and FGFR3-WHSC1(1). Of note no FGFR4 gene fusion was observed in this large series. [7] Preliminary pre-clinical data support that these fusions represent important therapeutic targets. For instance stable cell lines harboring FGFR3-BAIAP2L1,
FGFR3-TACC3, and FGFR2-CCDC6 fusions showed expression of active FGFR fusion kinases and activation of downstream mitogen-activated protein kinase ERK1/2 and the transcription factor STAT1. [12] The presence of FGFR fusions (FGFR3-BAIAP2L1) not only enhanced tumor cell proliferation, but also led to significant sensitivity to small kinase inhibitors (PD173074) in preclinical cellular and xenograft bladder cancer models, in contrast with FGFR3 mutant cell lines, which were not sensitive to kinase inhibition. [12] FGFR1-TACC1 fusion targeted therapy also showed anti-tumor effects in preclinical GBM model. [13] Cholangiocarcinoma mice model harboring FGFR2-AHCYL1, FGFR2-CCDC6, and FGFR2-BICC1 was sensitive to treatment with FGFR kinase inhibitors BGJ398 and PD173074. [16, 17]

TACC3 gene has been identified as an important partner of these FGFR fusions and associated with the pathogenesis of several solid tumors. [18-20] TACC3 (transforming acidic coiled-coil containing protein 3 ) belongs to the TACC gene family, which also includes TACC1 and TACC2. TACC3 protein has a coiled-coil domain at the $\mathrm{C}$ terminus, known as the TACC domain, which promotes stability and organization of mitotic spindle. [21]

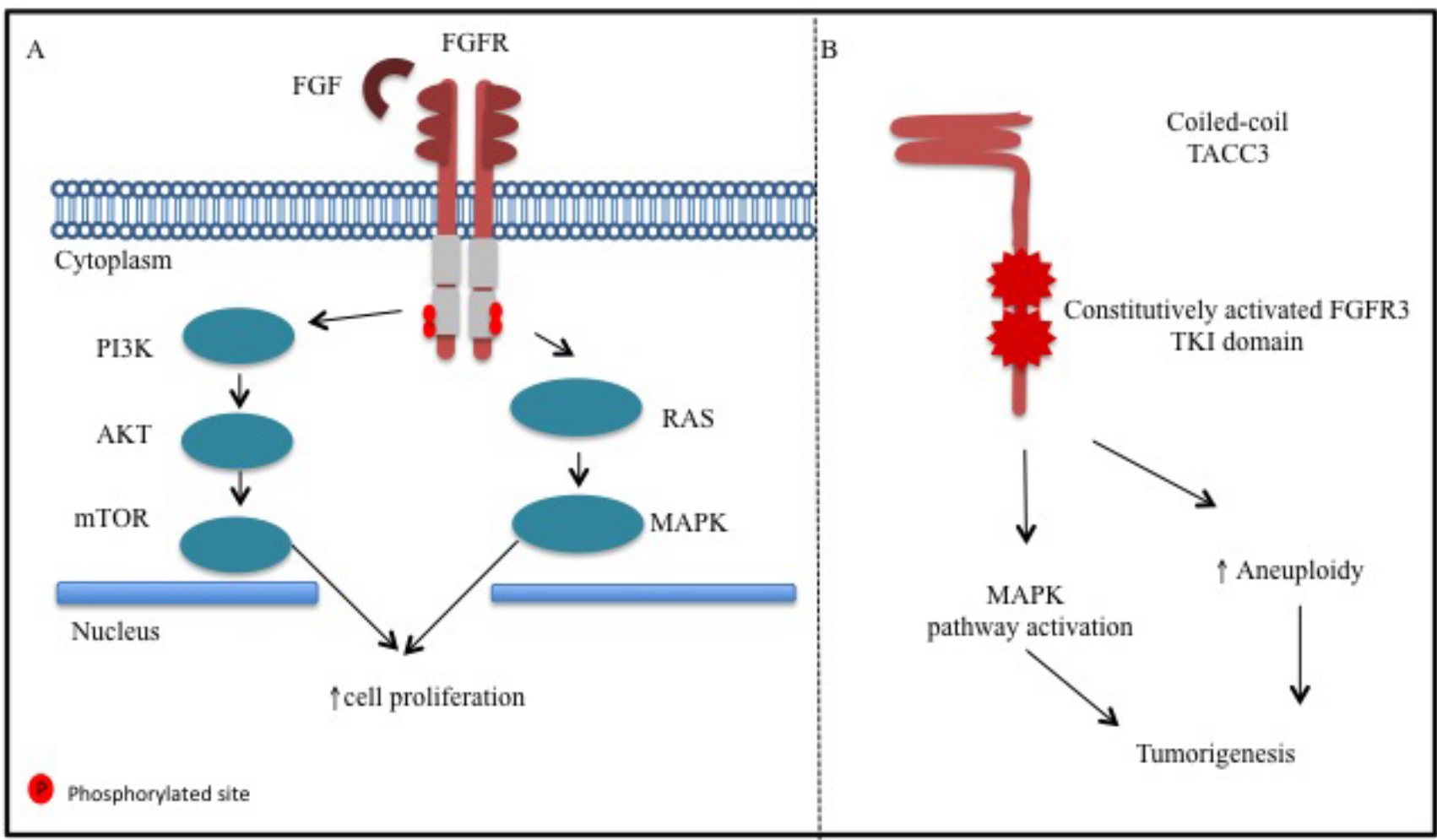

Figure 1: A. Fibroblast growth factor receptor (FGFR) has intra-cellular tyrosine kinase activity triggered by fibroblast growth factor (FGF) ligand. Its activation leads to FGFR transphosphorylation and activation of protein of ras oncogene (RAS)/mitogen-activated protein kinase (MAPK) and phosphatidylinositol 3-Kinase (PI3K) signaling pathways. B. Fibroblast growth factor receptor3-transforming acidic coiled-coil containing protein 3(FGFR3-TACC3) fusion protein harbors constitutively activated tyrosine kinase domain, which activates mitogen-activated protein kinase (MAPK) pathway. Also, FGFR3-TACC3 localizes to mitotic spindle poles, induces mitotic, chromosomal segregation defects and triggers aneuploidy. 
FGFR3-TACC3 fusions were first described in glioblastoma multiforme (GBM) and bladder urothelial tumors. [13, 15] Subsequent manuscripts underscored the low frequency of FGFR3-TACC3 gene fusions across different tumor types.

Among the 4853 tumors samples analyzed by Helsten et al. only 28 exhibited FGFR gene fusions, and 14 samples had FGFR3-TACC3 fusions. Accompanying genomic aberrations observed primarily affected TP53 tumor suppressor gene, AKT/mTOR/PTEN pathway and cell cycle control genes (i.e., CNNE1, CDK2 and 4) (Table 1). [7]

FGFR3-TACC3 fusions are formed by rare intrachromosomal rearrangements located within $150 \mathrm{~kb}$ of the FGFR3 gene on chromosome 4p16 (Figure 2). [13] It has been proposed that the fusion, which occurs via a tandem duplication event, leads to loss of an miR-99a binding site within the 3'-untranslated region (3'- UTR) of FGFR3, releasing FGFR3 signaling from miR-99adependent inhibition and enhancing tumor progression relative to wild type FGFR3. [22] Given the close proximity of the FGFR3 and TACC 3 genes, identification of the fusion by FISH is technically challenging. [23] Therefore the most common methods have involved transcriptomic analysis by RNA-seq and RT-PCR in addition to whole-genome sequencing. [7, 13, 23] Di Stefano et al. have also utilized immunostaining of the $\mathrm{N}$ terminus of FGFR3 and found uniform overexpression of FGFR3 in a subset of glioblastoma multiforme (GBM) cases with FGRF3-TACC fusions that were identified by RT-PCR. [23] Those findings demonstrate that detection of FGFR3 amplification by IHC or IF may serve as a method to screen for FGRF3-TACC fusions which is clinically relevant since RNA sequencing is not common practice. [24] The fusion protein exhibits constitutive kinase activity, induces mitotic, chromosomal segregation defects and triggers aneuploidy (Figure 1B). [13] The presence of the TACC coiled-coil domain increases the activity of FGFR3 through more promiscuous constitutive phosphorylation of tyrosine kinase residues within the FGFR3 protein, and preferential MAPK kinase activation (Figure 1A). [25] Moreover, preclinical and clinical results have shown that FGFR inhibitors can block the tyrosine kinase activity of this fusion protein.

Treatment of nasopharyngeal carcinoma cells carrying the FGFR3-TACC3 fusion with FGFR inhibitor PD173074 inhibited cell proliferation. [26] RT4 urothelial carcinoma line harboring FGFR3-TACC3 fusion also

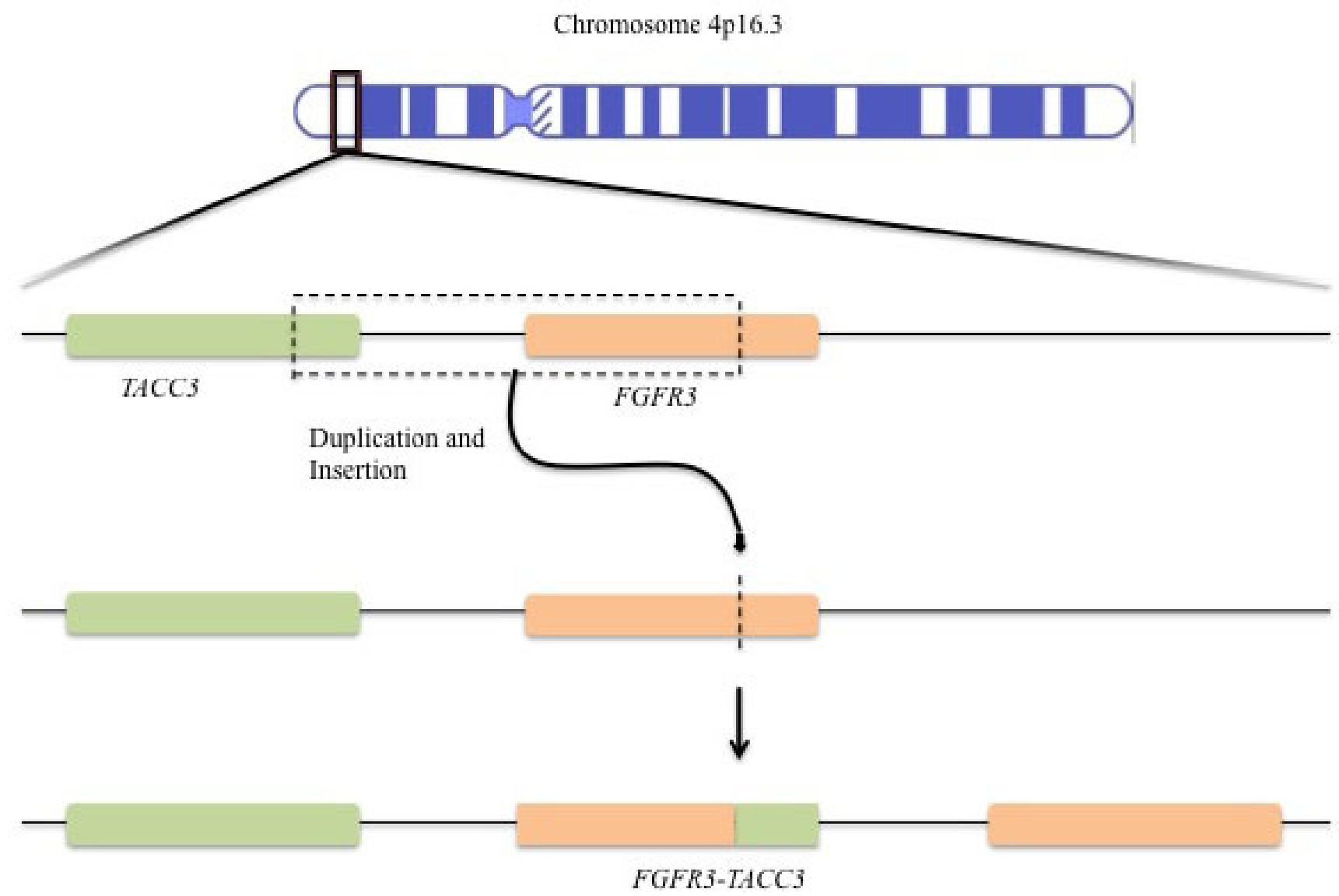

Figure 2: FGFR3-TACC3 gene fusion. Tandem duplication and insertion leads the fusion of the tyrosine kinase domain of $F G F R 3$ to the TACC domain of TACC3 


\begin{tabular}{|c|c|c|c|c|}
\hline Drug & $\begin{array}{l}\text { Mechanism of } \\
\text { action }\end{array}$ & Phase & Study population & $\begin{array}{l}\text { Clinicaltrials. } \\
\text { gov } \\
\text { Identification } \\
\end{array}$ \\
\hline BGJ398 & FGFR1-3 TKI & 2 & $\begin{array}{l}\text { Advanced or metastatic cholangiocarcinoma with FGFR2 Gene } \\
\text { Fusions or Other FGFR genetic alterations who failed or are } \\
\text { intolerant to platinum-based Chemotherapy }\end{array}$ & NCT02150967 \\
\hline $\begin{array}{l}\text { BGJ398/ } \\
\text { BYL719 }\end{array}$ & FGFR1-3 TKI & $1 \mathrm{~b}$ & $\begin{array}{l}\text { Refractory solid tumor with PIK3CA mutations in all patients } \\
\text { in dose escalation and expansion with or without documented } \\
\text { genetic alterations in FGFR depending upon dose expansion } \\
\text { cohort }\end{array}$ & NCT01928459 \\
\hline BGJ398 & FGFR1-3 TKI & 2 & $\begin{array}{l}\text { Histologically confirmed GBM and/or other glioma subtypes } \\
\text { with } F G F R 1-T A C C 1, F G F R 3-T A C C 3 \text { fusion and/or activating } \\
\text { mutation in } F G F R 1,2 \text { or } 3\end{array}$ & NCT01975701 \\
\hline BGJ 398 & FGFR1-3 TKI & 1 & Advanced solid tumor Having alterations of the FGF-R pathway & NCT01697605 \\
\hline BLU-554 & FGFR4 TKI & 1 & $\begin{array}{l}\text { Refractory HCC or refractory advanced solid tumor other than } \\
\text { HCC that has evidence of aberrant FGF19/FGFR4 pathway } \\
\text { activity }\end{array}$ & NCT02508467 \\
\hline BT-701 & $\begin{array}{l}\text { Anti FGFR-3 } \\
\text { antibody }\end{array}$ & 2 & $\begin{array}{l}\text { Refractory UC of the bladder cancer or transitional cell } \\
\text { carcinoma arising in another location of the urinary tract, } \\
\text { including urethra, ureter, and renal pelvis with positive FGFR3 } \\
\text { expression on IHC }\end{array}$ & NCT02401542 \\
\hline Debio 1347-101 & $\begin{array}{l}\text { FGFR1-3 } \\
\text { inhibitor }\end{array}$ & 1 & $\begin{array}{l}\text { Advanced solid malignancies, whose tumors have an alteration } \\
\text { of the } F G F R 1,2 \text { or } 3 \text { genes, for whom standard treatment does } \\
\text { not exist or is not indicated }\end{array}$ & NCT01948297 \\
\hline Dovitinib & $\begin{array}{l}\text { Multikinase } \\
\text { inhibitor } \\
\text { including } \\
\text { FGFR1-3 } \\
\end{array}$ & 2 & Refractory advanced/metastatic scirrhous gastric carcinoma & NCT01576380 \\
\hline Dovitinib & $\begin{array}{l}\text { Multikinase } \\
\text { inhibitor } \\
\text { including } \\
\text { FGFR1-3 } \\
\end{array}$ & 2 & $\begin{array}{l}F G F R 1 \text { amplified and non-amplified metastatic HER2 negative } \\
\text { breast cancer }\end{array}$ & NCT00958971 \\
\hline Dovitinib & $\begin{array}{l}\text { Multikinase } \\
\text { inhibitor } \\
\text { including } \\
\text { FGFR1-3 } \\
\end{array}$ & 2 & $\begin{array}{l}\text { BCG refractory UC patients with tumor fibroblast growth factor } \\
\text { receptor 3(FGFR3) mutations or over-expression }\end{array}$ & NCT01732107 \\
\hline \multicolumn{5}{|c|}{$\begin{array}{l}\text { Abbreviations: Fibroblast growth factor (FGF), fibroblast growth factor receptor (FGFR), not reported (NR), estrogen } \\
\text { receptor positive (ER+), tyrosine kinase inhibitor (TKI), bacillus calmette-Guerin (BCG), small cell lung cancer (SCLC), } \\
\text { Non-small cell lung cancer (NSCLC), squamous non-small cell lung cancer (sqNSCLC), pilot study (PS), glioblastoma } \\
\text { multiforme (GBM), hepatocellular carcinoma (HCC), Malignant pleural mesothelioma (MPM), immunohistochemistry } \\
\text { (IHC), urothelial carcinoma (UC). } \\
\text { www.clinicaltrials.gov accessed on April } 22^{\text {nd }} 2016\end{array}$} \\
\hline
\end{tabular}

exhibited sensitivity to this same FGFR inhibitor in a xenograft model. [12] Similar results were seen in GBM in vivo and in vitro models carrying the FGFR3$T A C C 3$ fusions, which was not only associated oncogenic transformation but also exhibited significant sensitivity to FGFR inhibitor JNJ-42756493. [13, 22, 23]

The clinical relevance of FGFR3-TACC3 has been underscored by preliminary results from clinical studies and case reports of tumor responses to the treatment with FGFR inhibitors. For instance, the phase I trial with FGFR inhibitor JNJ-42756493 including 65 patients with advanced solid tumors included 4 patients with FGFR3TACC3 translocation. [10] Three partial responses (two confirmed and one unconfirmed) were seen among 3 patients with urothelial, two of which cancer harbored
FGFR3-TACC3 fusion. One of these patients stayed on treatment for about 10 months. Another confirmed partial response was observed in a patient with glioblastoma with FGFR3-TACC3. Tumor shrinkage was also seen in a patient with adrenal carcinoma with FGFR3-TACC3/ FGFR2-CCDC6 (FGFR3-TACC3 being the predominant translocation), who received treatment for 10 months before disease progression. In agreement with preclinical results, these results suggest that FGFR3-TACC3 fusion is indeed an actionable therapeutic target. 


\begin{tabular}{|c|c|c|c|c|}
\hline Drug & $\begin{array}{l}\text { Mechanism } \\
\text { of action }\end{array}$ & Phase & Study population & $\begin{array}{l}\text { Clinicaltrials. } \\
\text { gov } \\
\text { Identification } \\
\end{array}$ \\
\hline Dovitinib & $\begin{array}{l}\text { Multikinase } \\
\text { inhibitor } \\
\text { including } \\
\text { FGFR1-3 }\end{array}$ & 2 & $\begin{array}{l}\text { Either FGFR2 mutated or wild-type advanced and/or metastatic } \\
\text { endometrial cancer }\end{array}$ & NCT01379534 \\
\hline Dovitinib & $\begin{array}{l}\text { Multikinase } \\
\text { inhibitor } \\
\text { including } \\
\text { FGFR1-3 } \\
\end{array}$ & 2 & $\begin{array}{l}\text { Refractory solid tumors with mutations or translocations of FGFR, } \\
P D G F R \text {, VEGF, cKIT, FLT3, CSFR1, Trk and RET }\end{array}$ & NCT01831726 \\
\hline Dovitinib & \begin{tabular}{|l} 
Multikinase \\
inhibitor \\
including \\
FGFR1-3
\end{tabular} & 2 & Advanced urothelial cancer with mutated or wild $F G F R 3$ mutated & NCT00790426 \\
\hline Divotinib & $\begin{array}{l}\text { Multikinase } \\
\text { inhibitor } \\
\text { including } \\
\text { FGFR1-3 }\end{array}$ & 2 & $\begin{array}{l}\text { Metastatic or unresectable gastric cancer harboring } F G F R 2 \\
\text { amplification after failure of first or second sine chemotherapy }\end{array}$ & NCT01719549 \\
\hline Dovitinib & $\begin{array}{l}\text { Multikinase } \\
\text { inhibitor } \\
\text { including } \\
\text { FGFR1-3 } \\
\end{array}$ & NR & $\begin{array}{l}\text { Refractory sqNSCLC with } F G F R \text { amplification (FISH }>5 \text { copies } \\
\text { of genes) }\end{array}$ & NCT01861197 \\
\hline Dovitinib & \begin{tabular}{|l} 
Multikinase \\
inhibitor \\
including \\
FGFR1-3 \\
\end{tabular} & 2 & $\begin{array}{l}\text { Refractory progressive NSCLC and colorectal cancer status post } \\
\text { antiangiogenic treatment }\end{array}$ & NCT01676714 \\
\hline Dovitinib & $\begin{array}{l}\text { Multikinase } \\
\text { inhibitor } \\
\text { including } \\
\text { FGFR1-3 }\end{array}$ & PS & Refractory renal cell carcinoma & NCT01791387 \\
\hline \multicolumn{5}{|c|}{$\begin{array}{l}\text { Abbreviations: Fibroblast growth factor (FGF), fibroblast growth factor receptor (FGFR), not reported (NR), estrogen } \\
\text { receptor positive (ER+), tyrosine kinase inhibitor (TKI), bacillus calmette-Guerin (BCG), small cell lung cancer (SCLC) } \\
\text { Non-small cell lung cancer (NSCLC), squamous non-small cell lung cancer (sqNSCLC), pilot study (PS), glioblastoma } \\
\text { multiforme (GBM), hepatocellular carcinoma (HCC), Malignant pleural mesothelioma (MPM), immunohistochemistry } \\
\text { (IHC), urothelial carcinoma (UC). www.clinicaltrials.gov accessed on April } 22^{\text {nd }} 2016 \text {. }\end{array}$} \\
\hline
\end{tabular}

\section{PREVALENCE OF FGFR3-TACC3 FUSION IN SOLID TUMORS}

\section{Gliomas}

The first report of this fusion emerged from a small subset of patients with GBM with 2 out of 97 samples harboring FGFR3-TACC3. [13] A subsequent study with 795 cases of gliomas (584 GBMs and 211 grade II-III gliomas) described 17 cases (2.9\%) of FGFR3-TACC3 genomic fusions among the GBM group, and 3 cases among lower grade gliomas. [23] Amplicons ranged from 928 bp (for FGFR3exon18-TACC3exon13) to $1,706 \mathrm{bp}$ (for FGFR3ex 18-TACC3ex4). All tested FGFR3-TACC3 positive tumors showed strong expression of FGFR 3 by tumor cells on immunohistochemistry (IHC). Epidermal growth factor receptor gene $(E G F R)$ amplification showed significant negative correlation with FGFR3-TACC3 status; $C D K 4$ and $M D M 2$ amplification had significant positive correlation with FGFR3-TACC3 (CDK4 amplification was seen in 7/16 FGFR3-TACC3 positive cases). No statistically significant correlation was seen between FGFR3-TACC3 fusions and other genetic and epigenetic alterations (CDKN2A deletion, TERT promoter mutations, gain of chromosome $7 \mathrm{p}$, loss of chromosome $10 \mathrm{q}$, and methylation of the $M G M T$ promoter). Parker et al. also reported higher frequency of FGFR3-TACC3 fusions in GBMs when compared to gliomas. [22] Four out of $48(8.3 \%)$ GBMs tested were positive for this fusion, whereas none of the 43 low-grade glioma samples showed this translocation. In addition, 2 out 157 GBM (1.2\%) and 2 out of 461 low grade gliomas $(0.4 \%)$ samples from The Cancer Genome Atlas (TCGA) dataset tested positive for FGFR3-TACC3 fusions which reinforced the notion that this fusion is more common in high grade gliomas. [14] In another series 3 out of 59 patients with primary GBM harbored this fusion gene. [27] $\mathrm{Wu}$ et al. reported 2 cases of GBM harboring FGFR3-TACC3 fusion from the TGCA database. [12] In summary, it is estimated that $1.2-8.3 \%$ of GBMs will carry this translocation. 


\begin{tabular}{|c|c|c|c|c|}
\hline Drug & \begin{tabular}{ll|}
$\begin{array}{l}\text { Mechanism of } \\
\text { action }\end{array}$ \\
\end{tabular} & Phase & Study population & $\begin{array}{l}\text { Clinicaltrials.gov } \\
\text { Identification }\end{array}$ \\
\hline Dovitinib & $\begin{array}{l}\text { Multikinase } \\
\text { inhibitor } \\
\text { including } \\
\text { FGFR1-3 }\end{array}$ & 2 & Refractory gastrointestinal stromal tumors & NCT01440959 \\
\hline E7090 & $\begin{array}{l}\text { FGF/FGFR } \\
\text { pathway inhibitor }\end{array}$ & 1 & $\begin{array}{l}\text { Refractory solid tumors dose expansion will enroll patients } \\
\text { with tumor expressing genetic abnormality in FGF/FGFR } \\
\text { pathway. }\end{array}$ & NCT02275910 \\
\hline FGF401 & FGFR4-TKI & $1 / 2$ & $\begin{array}{l}\text { Hepatocellular carcinoma or solid malignancies } \\
\text { characterized by positive FGFR4 and Klotho Berta (KLB) } \\
\text { expression }\end{array}$ & NCT02325739 \\
\hline FPA144 & $\begin{array}{l}\text { FGFR2b } \\
\text { antibody }\end{array}$ & 1 & Refractory solid tumors & NCT02318329 \\
\hline GSK3052230 & $\begin{array}{l}\text { FGF ligand trap } \\
\text { (extra-cellular } \\
\text { domain of } \\
\text { FGFR1 fused } \\
\text { with the Fc } \\
\text { region of IgG1) }\end{array}$ & $1 b$ & $\begin{array}{l}\text { Refractory progressive sqNSCLC with FGFR1 gene } \\
\text { amplification or MPM with measurable disease }\end{array}$ & NCT01868022 \\
\hline INCB054828 & FGFR 1-3 TKI & 1 & $\begin{array}{l}\text { Refractory solid tumors; on dose expansion subjects with } \\
\text { sqNSCLC, gastric cancer, UC, endometrial cancer, multiple } \\
\text { myeloma, or MPNs that have a tumor or malignancy that has } \\
\text { been evaluated and confirmed to harbor genetic alterations } \\
\text { in FGF or } F G F R \text { genes }\end{array}$ & NCT02393248 \\
\hline JNJ-42756493 & Pan FGFR TKI & 2 & $\begin{array}{l}\text { Metastatic or surgically unresectable UC that harbor specific } \\
\text { FGFR genomic alterations }\end{array}$ & NCT02365597 \\
\hline JNJ-42756493 & Pan FGFR TKI & 1 & $\begin{array}{l}\text { Refractory HCC and for expansion phase participants must } \\
\text { have } F G F 19 \text { amplification in addition }\end{array}$ & NCT02421185 \\
\hline JNJ-42756493 & $\begin{array}{l}\text { Pan FGFR TKI } \\
\text { inhibitor }\end{array}$ & $2 \mathrm{a}$ & $\begin{array}{l}\text { Asian patients with advanced Non-small-cell lung cancer, } \\
\text { urothelial cancer, gastric cancer, esophageal cancer } \\
\text { or cholangiocarcinoma with FGFR gene mutation or } \\
\text { translocation. }\end{array}$ & NCT02699606 \\
\hline \begin{tabular}{|l|}
$J N J-42756493$ \\
\end{tabular} & Pan FGFR TKI & 1 & Refractory solid tumors and lymphomas & NCT01962532 \\
\hline \multicolumn{5}{|c|}{$\begin{array}{l}\text { Abbreviations: Fibroblast growth factor (FGF), fibroblast growth factor receptor (FGFR), not reported (NR), estrogen } \\
\text { receptor positive (ER+), tyrosine kinase inhibitor (TKI), bacillus calmette-Guerin (BCG), small cell lung cancer (SCLC), } \\
\text { Non-small cell lung cancer (NSCLC), squamous non-small cell lung cancer (sqNSCLC), pilot study (PS), glioblastoma } \\
\text { multiforme (GBM), hepatocellular carcinoma (HCC), Malignant pleural mesothelioma (MPM), immunohistochemistry } \\
\text { (IHC), urothelial carcinoma (UC). www.clinicaltrials.gov accessed on April } 22^{\text {nd }} 2016\end{array}$} \\
\hline
\end{tabular}

\section{Urothelial cancer}

The TCGA project reported a comprehensive genomic analysis of 131 high-grade muscle invasive urothelial bladder carcinomas including gene fusions. Three cases of tumors with FGFR3-TACC3 fusion were reported ( 2.3\%). The breakpoints were in intron 10 of TACC 3 and intron 16 ( 2 cases) or exon 17 (1 case) of FGFR3. [28] Two cases among 99 samples analyzed showed two distinct FGFR3-TACC3 genomic fusions; first, intron 17 of FGFR3 with intron 10 of TACC3 resulting in exon 17 of FGFR3 being spliced 5 ' to exon 11 of TACC 3 in the fuse mRNA; second, intron 17 of FGFR3 with exon 4 of TACC 3 at the gene level and in the fused mRNA, exon 17 and fragment of intron 17 in FGFR3, and fragment of exon 4 in $T A C C 3$ were merged into a novel exon. [29] Analysis of 250 samples of bladder urothelial carcinoma by RNA-seq detected FGFR3-TACC 3 in 5 specimens (2\%). [14] Helsten et al. described 126 cases of urothelial carcinomas and 4 cases (3\%) of FGFR3-TACC3 translocations were observed. [7] Williams et al. reported results of analysis of 2 tumor samples positive for FGFR3 exon 18 and TACC3 exon 13 fusions among 32 selected bladder carcinoma samples. [15] Taken together, a total of 14 cases of urothelial carcinoma carrying FGFR3-TACC 3 translocation have been described with an estimated incidence of $2.6 \%$ among the 539 cases described above.

\section{Non-small cell lung cancer}

RNA sequencing of 492 sqNSCLC from the TCGA showed only 3 cases of FGFR 3 -TACC 3 fusions; none of 513 cases of adenocarcinomas harbored this translocation. [14] Another study describing genomic analysis of 675 


\begin{tabular}{|c|c|c|c|c|}
\hline Drug & $\begin{array}{l}\text { Mechanism of } \\
\text { action }\end{array}$ & Phase & Study population & $\begin{array}{l}\text { Clinicaltrials. } \\
\text { gov } \\
\text { Identification }\end{array}$ \\
\hline JNJ-42756493 & Pan FGFR TKI & 1 & $\begin{array}{l}\text { Solid malignancy or lymphoma that is metastatic or } \\
\text { unresectable, and for which standard curative treatment is } \\
\text { no longer effective }\end{array}$ & NCT01703481 \\
\hline Lucitanib & $\begin{array}{l}\text { VEGFR-FGFR } \\
\text { Tyrosine Kinase } \\
\text { Inhibitor }\end{array}$ & $1 / 2 \mathrm{a}$ & $\begin{array}{l}\text { Advanced solid tumors, relapsed or refractory to standard } \\
\text { therapy. For the dose expansion, patients should have } \\
\text { tumors bearing FGFR1 or 11q 12-14 amplification, } \\
\text { assessed by FISH or CGH array, or "sensitive" to } \\
\text { antiangiogenic treatment }\end{array}$ & NCT01283945 \\
\hline Lucitanib & $\begin{array}{l}\text { Multikinase } \\
\text { inhibitor } \\
\text { including FGFR }\end{array}$ & 2 & $\begin{array}{l}\text { FGFRl-amplified or non-amplified ER }+ \text { metastatic breast } \\
\text { cancer }\end{array}$ & NCT02053636 \\
\hline Lucitanib & $\begin{array}{l}\text { Multikinase } \\
\text { inhibitor } \\
\text { including FGFR }\end{array}$ & 2 & Metastatic breast cancer & NCT02202746 \\
\hline Lucitanib & $\begin{array}{l}\text { Multikinase } \\
\text { inhibitor } \\
\text { including FGFR }\end{array}$ & 2 & $\begin{array}{l}\text { SCLC or NSCLC with tumor tissue based genetic } \\
\text { alterations: } F G F R 1, F G F R 2, F G F R 3, V E G F A \text {, or } P D G F R \alpha \\
\text { amplification; any } F G F R 1, F G F R 2 \text {, or } F G F R 3 \text { gene fusion; } \\
F G F R 1, F G F R 2 \text {, or } F G F R 3 \text { activating mutation }\end{array}$ & NCT02109016 \\
\hline LY3076226, & $\begin{array}{l}\text { FGFR3 } \\
\text { Antibody-Drug } \\
\text { Conjugate }\end{array}$ & 1 & Advanced refractory solid tumors with $F G F R 3$ alterations. & NCT02529553 \\
\hline Nintedanib & $\begin{array}{l}\text { Multikinase } \\
\text { inhibitor } \\
\text { including FGFR }\end{array}$ & PS & $\begin{array}{l}\text { Advanced refractory NSCLC with mutations, } \\
\text { rearrangement and fusion involving RET oncogene, or } \\
\text { abnormalities (non-synonymous SNV or amplification) in } \\
\text { the nintedanib target genes VEGFR1-3, TP53, PDGFR- } A \text {, } \\
P D G F R-B \text {, and } F G F R 1-3 \text {. }\end{array}$ & NCT02299141 \\
\hline Nintedanib & $\begin{array}{l}\text { Multikinase } \\
\text { inhibitor } \\
\text { including FGFR }\end{array}$ & 2 & Refractory salivary gland tumors & NCT02558387 \\
\hline Nintedanib & $\begin{array}{l}\text { Multikinase } \\
\text { inhibitor } \\
\text { including FGFR }\end{array}$ & 2 & $\begin{array}{l}\text { Refractory small Cell Lung Cancer Patients Who Have } \\
\text { Previously Benefited From First-line Platinum-based } \\
\text { Chemotherapy }\end{array}$ & NCT02152059 \\
\hline \multicolumn{5}{|c|}{$\begin{array}{l}\text { Abbreviations: Fibroblast growth factor (FGF), fibroblast growth factor receptor (FGFR), not reported (NR), estro- } \\
\text { gen receptor positive (ER+), tyrosine kinase inhibitor (TKI), bacillus calmette-Guerin (BCG), small cell lung cancer } \\
\text { (SCLC), Non-small cell lung cancer (NSCLC), squamous non-small cell lung cancer (sqNSCLC), pilot study (PS), glio- } \\
\text { blastoma multiforme (GBM), hepatocellular carcinoma (HCC), Malignant pleural mesothelioma (MPM), immunohisto- } \\
\text { chemistry (IHC), urothelial carcinoma (UC). www.clinicaltrials.gov accessed on April } 22^{\text {nd }} 2016\end{array}$} \\
\hline
\end{tabular}

cases of NSCLC showed only one case of FGFR3-TACC3 fusion (breakpoint not specified), this was associated with existing CDKN2A-loss and MDM2 amplification. [7] $\mathrm{Wu}$ et al. reported through analysis of the TGCA dataset 4 cases of sqNSCLC harboring FGFR3-TACC3 fusion. [12] Capelletti et al. identified 3 out 576 patients with adenocarcinoma of the lung harboring FGFR3-TACC3. [30] Fusion variants identified included exon 17 FGFR3 to exon exon 8 of TACC3; exon 17 of FGFR3 and exon 11 of TACC3; and exon 17 of FGFR3 to exon 4 TACC3 resulting in an overall prevalence of $0.5 \%$. An additional analysis of 1,328 NSCLC samples revealed 15 FGFR3TACC3 fusion variants identified through RT-PCR [31] . Histological distribution was as follows: 6/1016 (0.6\%) adenocarcinomas and 9/312 (2.9\%) squamous cell carcinoma of the lung suggesting the FGFR3-TACC3 fusions are more frequent in sqNSCLC. FGFR3-TACC3 fusion correlated with positive smoking history and male gender in univariate analysis. Tumor size $>3 \mathrm{~cm}$ correlated with FGFR3 fusions independently in multivariate modeling. FGFR3-TACC3 fusions were distributed as follows: E18:E11 2 cases, E17:E11 9 cases, E17:E8 1 case, E17:E5 1 case, and E17:E10 2 cases.

Another cohort of patients from Korea was analyzed and only 2 cases of FGFR3-TACC 3 fusion were detected (E17:E8 and E18:E9). The same author reviewed the samples of the TCGA database and found 4 out of 178 samples positive for this fusion. [32] Two more cases of FGFR3 E18 fused with TACC3 E10 were reported in sqNSCLC. [33] The TCGA dataset reported genomic 


\begin{tabular}{|c|c|c|c|c|}
\hline Drug & $\begin{array}{l}\text { Mechanism of } \\
\text { action }\end{array}$ & Phase & Study population & $\begin{array}{l}\text { Clinicaltrials. } \\
\text { gov } \\
\text { Identification }\end{array}$ \\
\hline Nintedanib & $\begin{array}{l}\text { Multikinase } \\
\text { inhibitor } \\
\text { including FGFR }\end{array}$ & PS & Refractory sqNSCLC & NCT01948141 \\
\hline Nintedanib & $\begin{array}{l}\text { Multikinase } \\
\text { inhibitor } \\
\text { including FGFR }\end{array}$ & 2 & $\begin{array}{l}\text { Advanced } F G F R 3 \text { mutated, } F G F R 3 \text { overexpressed, or FGFR3 } \\
\text { wild type UC of urinary bladder, urethra, ureter, and renal pelvis } \\
\text { and who have failed platinum-based chemotherapy }\end{array}$ & NCT02278978 \\
\hline Orantinib & $\begin{array}{l}\text { Multikinase } \\
\text { inhibitor } \\
\text { including FGFR }\end{array}$ & $1 / 2$ & Refractory HCC & NCT00784290 \\
\hline Pazopanib & $\begin{array}{l}\text { Multikinase } \\
\text { inhibitor } \\
\text { including FGFR }\end{array}$ & PS & $\begin{array}{l}\text { Refractory solid tumors FGFR2 amplified and sensitive to } \\
\text { pazopanib by Avatar scan }\end{array}$ & NCT02691767 \\
\hline Pazopanib & $\begin{array}{l}\text { Multikinase } \\
\text { inhibitor } \\
\text { including FGFR }\end{array}$ & PS & $\begin{array}{l}\text { Refractory solid tumors harboring } F G F R 2 \text { amplification or } \\
\text { FGFR2 mutation }\end{array}$ & NCT02450136 \\
\hline \begin{tabular}{|l|} 
PRN1371 \\
\end{tabular} & FGFR1-4 TKI & 1 & Adults with advanced solid tumors & NCT02608125 \\
\hline Ponatinib & $\begin{array}{l}\text { Multikinase } \\
\text { inhibitor } \\
\text { including pan- } \\
\text { FGFR }\end{array}$ & 2 & Advanced biliary cancer with $F G F R 2$ fusion & NCT02265341 \\
\hline Ponatinib & $\begin{array}{l}\text { Multikinase } \\
\text { inhibitor } \\
\text { including pan- } \\
\text { FGFR }\end{array}$ & 2 & $\begin{array}{l}\text { Refractory solid tumor or chronic hematologic solid malignancy } \\
\text { with activating genomic alterations in } F G F R \text { (mutations, fusions } \\
\text { or amplifications [ }>6 \text { copies]) or activating genomic alterations } \\
\text { in } K I T \text {, platelet-derived growth factor receptor alpha }[P D G F R \alpha] \\
\text { ret proto-oncogene }[R E T], A B L \text { proto-oncogene } 1 \text {, non-receptor } \\
\text { tyrosine kinase }[A B L I] \text { and fms-related tyrosine kinase } 3[F L T 3]\end{array}$ & NCT02272998 \\
\hline \multicolumn{5}{|c|}{$\begin{array}{l}\text { Abbreviations: Fibroblast growth factor (FGF), fibroblast growth factor receptor (FGFR), not reported (NR), estrogen } \\
\text { receptor positive (ER+), tyrosine kinase inhibitor (TKI), bacillus calmette-Guerin (BCG), small cell lung cancer (SCLC) } \\
\text { Non-small cell lung cancer (NSCLC), squamous non-small cell lung cancer (sqNSCLC), pilot study (PS), glioblastoma } \\
\text { multiforme (GBM), hepatocellular carcinoma (HCC), Malignant pleural mesothelioma (MPM), immunohistochemistry } \\
\text { (IHC), urothelial carcinoma (UC). www.clinicaltrials.gov accessed on April } 22^{\text {nd }} 2016\end{array}$} \\
\hline
\end{tabular}

analysis through RT-PCR of 230 previously untreated adenocarcinomas of the lung and 178 previously untreated sqNSCLC; FGFR fusions were not reported in either series. [34, 35] In summary, FGFR3-TACC3 fusions are rare in NSCLC but seem to be more common in sqNSCLC histological type with an estimated prevalence consistently lower than $2.9 \%$.

\section{Cervical cancer}

Three cases of TACC3-FGFR 3 translocations break points in patients with advanced cervical carcinoma have been described with early evidence of clinical benefit from FGFR targeted treatment. [36] One of the cases was a metastatic recurrent to the lung adenosquamous carcinoma of the cervix. The metastatic tumor showed FGFR3-TACC3 fusion (break point intron 17 and TACC3 intron 10). Associated genomic aberrations were: AKT1 missense mutation, mTOR point mutation, ATRX truncating nonsense mutation. The patient was treated with FGFR targeted therapy achieving stable disease for 4 cycles. In the second case, the patient had well differentiated squamous cell carcinoma of the cervix stage. Tumor tissue from the original biopsy showed FGFR3-TACC3 fusion (break points FGFR3 intron 18 and TACC 3 intron 7) as well as BRAF 3 ' tandem duplication, activating PIK3CA missense mutation, $C D N K 2 A$ loss, and activating missense mutations in KRAS and HRAS. The third case was a squamous cell carcinoma of the cervix in which the following genomic aberrations were identified on hysterectomy specimen: FGFR3-TACC3 fusion (breakpoints at $F G F R 3$ intron 17 and $T A C C$ intron 10 ) and partial loss of $S T K 11$, and $R B 1$ loss.

Xiang et al. performed transcriptomic (RNA) followed by cDNA analysis of 285 cases of early stage carcinoma of the cervix; 11 cases of FGFR3-TACC 3 translocations were described (3.9\%) with 4 variants [FGFR3 (1_758) fused with TACC3 (549_838), FGFR3(1 758) fused with TACC3(648 838), FGFR3 (1 758) fused with TACC3 ( 648 838), and the most frequent variant FGFR3 (1 768) fused with TACC3(538_838)] . [37] There were four cases of squamous cell carcinoma, 3 cases of adenocarcinoma 3 cases of adenosquamous, and 1 small cell carcinoma. Other sporadic cases of FGFR3-TACC3 translocation in 


\begin{tabular}{|c|c|c|c|c|}
\hline Drug & $\begin{array}{l}\text { Mechanism of } \\
\text { action }\end{array}$ & Phase & Study population & $\begin{array}{l}\text { Clinicaltrials. } \\
\text { gov } \\
\text { Identification }\end{array}$ \\
\hline Regorafenib & \begin{tabular}{|l|} 
Multikinase \\
inhibitor \\
including FGFR
\end{tabular} & 2 & $\begin{array}{l}\text { Refractory epithelial ovarian carcinoma (serous, clear cell, } \\
\text { endometrioid, mucinous, mixed, carcinosarcoma and others), } \\
\text { fallopian tube and primary peritoneal carcinoma) }\end{array}$ & NCT02736305 \\
\hline Sunitinib & \begin{tabular}{|l|} 
Multikinase \\
inhibitor \\
including FGFR
\end{tabular} & PS & $\begin{array}{l}\text { Refractory solid tumors harboring } R E T \text { fusion positive or FGFR2 } \\
\text { amplification }\end{array}$ & NCT02450123 \\
\hline Sunitinib & \begin{tabular}{|l|} 
Multikinase \\
inhibitor \\
including FGFR
\end{tabular} & PS & $\begin{array}{l}R E T \text { fusion positive or } F G F R 2 \text { fusion/other } F G F R \text { mutation } \\
\text { Refractory solid tumor and/or specific sensitivity to Sunitinib by } \\
\text { Avatar scan }\end{array}$ & NCT02691793 \\
\hline TAS120 & FGFR TKI & 1 & $\begin{array}{l}\text { Advanced metastatic solid tumors with or without abnormalities } \\
\text { of FGF/FGFR who have failed all standard therapies or for } \\
\text { whom standard therapy does not exist or multiple myeloma } \\
\text { with amplification, mutation or translocation or other associated } \\
\text { abnormalities of FGF/FGFR who have failed all standard } \\
\text { therapies or for whom standard therapy does not exist }\end{array}$ & NCT02052778 \\
\hline U3-1784 & \begin{tabular}{|l|} 
FGFR4 \\
monoclonal \\
antibody
\end{tabular} & 1 & Refractory solid tumors & NCT02690350 \\
\hline XL228 & $\begin{array}{l}\text { Multi-targeted } \\
\text { kinase inhibitor } \\
\text { IGF-1R, Src, } \\
\text { FGFR, } \quad \text { and } \\
\text { BCR-Abl }\end{array}$ & 1 & Refractory solid tumors, lymphoma, or multiple myeloma & NCT00526838 \\
\hline \multicolumn{5}{|c|}{$\begin{array}{l}\text { Abbreviations: Fibroblast growth factor (FGF), fibroblast growth factor receptor (FGFR), not reported (NR), estrogen } \\
\text { receptor positive (ER+), tyrosine kinase inhibitor (TKI), bacillus calmette-Guerin (BCG), small cell lung cancer (SCLC), } \\
\text { Non-small cell lung cancer (NSCLC), squamous non-small cell lung cancer (sqNSCLC), pilot study (PS), glioblastoma } \\
\text { multiforme (GBM), hepatocellular carcinoma (HCC), Malignant pleural mesothelioma (MPM), immunohistochemistry } \\
\text { (IHC), urothelial carcinoma (UC). www.clinicaltrials.gov accessed on April } 22^{\text {nd }} 2016\end{array}$} \\
\hline
\end{tabular}

cervical carcinoma have been reported as part of genomic aberrations analysis of solid tumors: FGFR3-TACC3 fusion (intron 17-intron 7) one case of cervical carcinoma. [7]

\section{Head and neck cancer}

Among 411 head and neck SCC tumor samples analyzed using RNA sequencing data through the TGCA only 2 harbored FGFR3-TACC3 fusion. [14] Wu et al. reported two additional cases of head and neck cancer harboring this fusion. [12] An additional analysis of 279 head and neck SCC tumor samples from the TGCA dataset (172 oral cavity, 33 oropharynx, 72 laryngeal tumors) and cases of FGFR3-TACC3 were appreciated in two of the HPV+ samples. [38]

\section{Gastrointestinal malignancies}

FGFR3-TACC3 fusions are rare event as illustrated by analysis RNA sequencing of 856 tumor samples [hepatocellular carcinoma (194), colon (286), rectum (91), and gastric adenocarcinomas (285)] ; in which no tumor showed this translocation. [14]

\section{Other malignancies}

Two studies analyzed a total of 1594 cases of breast cancer no FGFR3-TACC3 fusion was reported. $[7,14]$ Single cases of carcinoma of unknown primary, endometrial carcinoma, renal cell carcinoma, gallbladder, papillary kidney tumor, and prostate adenocarcinoma harboring the FGFR3-TACC3 fusion have been described. $[7,14]$

\section{DISCUSSION}

In the recent years the field of medical oncology has witnessed unprecedented advances in the understanding of cancer biology. FGF/FGFR pathway is a thriving area of targeted drug development in a wide array of tumors (Table 3-9). FGFR3-TACC3 was first described in 2012 in two patients with GBM. [13] Since then FGFR3TACC3 fusion has been reported in numerous solid tumors including urothelial carcinoma, NSCLC, thyroid, and cervical carcinoma (Table 2). [12] In addition dataset analysis through bioinformatics, namely the TCGA dataset, yield other rarer instances in which this aberration can be found such as prostate cancer, head and neck cancer, and kidney papillary cancer. [14] 
The clinical relevance of FGFR3-TACC3 has been highlighted by 3 out of 4 partial responses among patients with tumors harboring FGFR3-TACC3 fusions treated with FGFR inhibitor JNJ-42756493. [10] In agreement with preclinical results, these results suggest that FGFR3$T A C C 3$ fusion is indeed an actionable therapeutic target. Furthermore taking into account the obvious limitation of the sparse clinical data thus far tumors harboring FGFR3TACC3 fusions seem to be more sensitive FGFR targeted therapies when compared to other FGFR aberrations. This is particularly important, as there are limited treatment options for patients with aggressive tumors in which FGFR3-TACC3 fusions have been described such as GBM and bladder cancer. Future studies should take into account that FGFR3-TACC3 fusion has shown positive correlations with $\mathrm{PI} 3 \mathrm{~K} / \mathrm{AKT} / \mathrm{mTOR}$ pathway, cell cycle control $(C D K 4, C D K 2$, and $C C N D 1)$, and $M D M 2$ aberrations (Table1). [23, 36, 39] The corollary to these concomitant findings is that one could hypothesize that the combined approach targeting FGFR3-TACC3 and its downstream oncogenic proteins may further enhance the efficacy of FGFR aberrant targeted therapy. Notwithstanding its rarity, FGFR3-TACC3 fusions are present in wide array of solid tumor types and its analysis should be an integral part of screening procedures in FGFR targeted trials in solid tumors.

Elucidation of the potential interaction between $F G F R$ and its fusions with the immune system is also warranted. Pre-clinical data suggest that FGFR3 mutations are exclusive to non-inflamed bladder cancers ( $\sim 30 \%$ of tumors), a subgroup characterized by absence of CD8 tumor infiltrating lymphocytes (CD8 TILs), worsen prognosis, and lower chance of responding to PD-L1 blockade. [40-42] The exclusion of CD8 TILs from the tumor microenvironment limits the benefit from immunotherapies in melanoma and might carry similar relevance to bladder cancer. [42] Nevertheless, these preliminary results highlight a possible link between FGFR pathway aberrations and immune modulation of tumor microenvironment that could be explored therapeutically.

\section{CONFLICTS OF INTEREST}

There is no conflict of interest.

\section{REFERENCES}

1. Carneiro BA, Costa R, Taxter T, Chandra S, Chae YK, Cristofanilli $\mathrm{M}$ and Giles FJ. Is Personalized Medicine Here? Oncology (Williston Park). 2016; 30:293-303, 307.

2. Chapman PB, Hauschild A, Robert C, Haanen JB, Ascierto P, Larkin J, Dummer R, Garbe C, Testori A, Maio M, Hogg D, Lorigan P, Lebbe C, et al. Improved survival with vemurafenib in melanoma with BRAF V600E mutation. The New England journal of medicine. 2011; 364:2507-
2516.

3. Maemondo M, Inoue A, Kobayashi K, Sugawara S, Oizumi S, Isobe H, Gemma A, Harada M, Yoshizawa H, Kinoshita I, Fujita Y, Okinaga S, Hirano H, Yoshimori K, Harada T, Ogura T, et al. Gefitinib or chemotherapy for non-small-cell lung cancer with mutated EGFR. The New England journal of medicine. $2010 ; 362: 2380-2388$.

4. Demetri GD, von Mehren M, Blanke CD, Van den Abbeele AD, Eisenberg B, Roberts PJ, Heinrich MC, Tuveson DA, Singer S, Janicek M, Fletcher JA, Silverman SG, Silberman SL, Capdeville R, Kiese B, Peng B, et al. Efficacy and safety of imatinib mesylate in advanced gastrointestinal stromal tumors. The New England journal of medicine. 2002; 347:472-480.

5. Touat M, Ileana E, Postel-Vinay S, Andre F and Soria JC. Targeting FGFR Signaling in Cancer. Clin Cancer Res. 2015; 21:2684-2694.

6. Gallo LH, Nelson KN, Meyer AN and Donoghue DJ. Functions of Fibroblast Growth Factor Receptors in cancer defined by novel translocations and mutations. Cytokine Growth Factor Rev. 2015; 26:425-449.

7. Helsten T, Elkin S, Arthur E, Tomson BN, Carter J and Kurzrock R. The FGFR Landscape in Cancer: Analysis of 4,853 Tumors by Next-Generation Sequencing. Clin Cancer Res. 2016; 22:259-67.

8. Nogova L, Cassier PA, Hidalgo M, Delord JP, Schuler MH, Lim WT, Camidge DR, Buettner R, Heukamp LC, Gardizi M, Scheffler S, Kambartel K, Ringeisen FP, Sen S, et al. Targeting FGFR1-amplified lung squamous cell carcinoma with the selective pan-FGFR inhibitor BGJ398. J Clin Oncol. 2014; 32:5.

9. Lecia V, Sequist PC, Varga V, Tabernero J, Schellens JH, Delord JP, LoRusso P, Camidge DR, Medina MH, Schuler M, Campone M, Tian GG, Wong S, Corral J, et al. Phase I study of BGJ398, a selective pan-FGFR inhibitor in genetically preselected advanced solid tumors. [abstract] . Proceedings of the 105th Annual Meeting of the American Association for Cancer Research; 2014 Apr 5-9; San Diego, CA Philadelphia (PA): AACR; Cancer Res 2014;74:Abstract nr CT326 doi:101158/15387445AM2014-CT326.

10. Tabernero J, Bahleda R, Dienstmann R, Infante JR, Mita A, Italiano A, Calvo E, Moreno V, Adamo B, Gazzah A, Zhong B, Platero SJ, Smit JW, et al. Phase I Dose-Escalation Study of JNJ-42756493, an Oral Pan-Fibroblast Growth Factor Receptor Inhibitor, in Patients With Advanced Solid Tumors. J Clin Oncol. 2015; 33:3401-3408.

11. Milind M. Javle RTS, Zhu A, Sadeghi S, Choo SP, Borad MJ, Lowery MA, El-Khoueiry A, Macarulla T, Philip PA, Oh DY, Van Cutsem E, Yeh KH, Isaacs R, McGarry C, Sen S, Bekaii-Saab TS. A phase 2 study of BGJ398 in patients (pts) with advanced or metastatic FGFR-altered cholangiocarcinoma (CCA) who failed or are intolerant to platinum-based chemotherapy. J Clin Oncol. 2016; 34.

12. Wu YM, Su F, Kalyana-Sundaram S, Khazanov N, Ateeq 
B, Cao X, Lonigro RJ, Vats P, Wang R, Lin SF, Cheng AJ, Kunju LP, Siddiqui J, Tomlins SA, Wyngaard P, Sadis S, et al. Identification of targetable FGFR gene fusions in diverse cancers. Cancer discovery. 2013; 3:636-647.

13. Singh D, Chan JM, Zoppoli P, Niola F, Sullivan R, Castano A, Liu EM, Reichel J, Porrati P, Pellegatta S, Qiu K, Gao Z, Ceccarelli M, Riccardi R, Brat DJ, Guha A, et al. Transforming fusions of FGFR and TACC genes in human glioblastoma. Science (New York, NY). 2012; 337:12311235.

14. Stransky N, Cerami E, Schalm S, Kim JL and Lengauer C. The landscape of kinase fusions in cancer. Nature communications. 2014; 5:4846.

15. Williams SV, Hurst CD and Knowles MA. Oncogenic FGFR3 gene fusions in bladder cancer. Human molecular genetics. 2013; 22:795-803.

16. Arai Y, Totoki Y, Hosoda F, Shirota T, Hama N, Nakamura H, Ojima H, Furuta K, Shimada K, Okusaka T, Kosuge T and Shibata T. Fibroblast growth factor receptor 2 tyrosine kinase fusions define a unique molecular subtype of cholangiocarcinoma. Hepatology. 2014; 59:1427-1434.

17. Wang Y, Ding X, Wang S, Moser CD, Shaleh HM, Mohamed EA, Chaiteerakij R, Allotey LK, Chen G, Miyabe K, McNulty MS, Ndzengue A, Knudson RA, Greipp PT, Clark KJ, Torbenson MS, et al. Antitumor effect of FGFR inhibitors on a novel cholangiocarcinoma patient derived xenograft mouse model endogenously expressing an FGFR2-CCDC6 fusion protein. Cancer letters. 2016.

18. Huang ZL, Lin ZR, Xiao YR, Cao X, Zhu LC, Zeng MS, Zhong $Q$ and Wen ZS. High expression of TACC3 in esophageal squamous cell carcinoma correlates with poor prognosis. Oncotarget. 2015; 6:6850-6861. doi: 10.18632/ oncotarget.3190.

19. Ha GH, Kim JL and Breuer EK. TACC3 is essential for EGF-mediated EMT in cervical cancer. PloS one. 2013; 8:e70353.

20. Lauffart B, Vaughan MM, Eddy R, Chervinsky D, DiCioccio RA, Black JD and Still IH. Aberrations of TACC1 and TACC3 are associated with ovarian cancer. BMC Womens Health. 2005; 5:8.

21. Hood FE and Royle SJ. Pulling it together: The mitotic function of TACC3. Bioarchitecture. 2011; 1:105-109.

22. Parker BC, Annala MJ, Cogdell DE, Granberg KJ, Sun Y, Ji P, Li X, Gumin J, Zheng H, Hu L, Yli-Harja O, Haapasalo H, Visakorpi T, Liu X, Liu CG, Sawaya R, et al. The tumorigenic FGFR3-TACC3 gene fusion escapes miR-99a regulation in glioblastoma. The Journal of clinical investigation. 2013; 123:855-865.

23. Di Stefano AL, Fucci A, Frattini V, Labussiere M, Mokhtari K, Zoppoli P, Marie Y, Bruno A, Boisselier B, Giry M, Savatovsky J, Touat M, Belaid H, Kamoun A, Idbaih A, Houillier C, et al. Detection, Characterization, and Inhibition of FGFR-TACC Fusions in IDH Wild-type Glioma. Clin Cancer Res. 2015; 21:3307-3317.
24. Byron SA, Van Keuren-Jensen KR, Engelthaler DM, Carpten JD and Craig DW. Translating RNA sequencing into clinical diagnostics: opportunities and challenges. Nat Rev Genet. 2016; 17:257-271.

25. Nelson KN, Meyer AN, Siari A, Campos AR, Motamedchaboki $\mathrm{K}$ and Donoghue DJ. Oncogenic Gene Fusion FGFR3-TACC3 is Regulated by Tyrosine Phosphorylation. Mol Cancer Res. 2016; 14:458-69.

26. Yuan L, Liu ZH, Lin ZR, Xu LH, Zhong Q and Zeng MS. Recurrent FGFR3-TACC3 fusion gene in nasopharyngeal carcinoma. Cancer biology \& therapy. 2014; 15:1613-1621.

27. Bao ZS, Chen HM, Yang MY, Zhang CB, Yu K, Ye WL, Hu BQ, Yan W, Zhang W, Akers J, Ramakrishnan V, Li J, Carter B, Liu YW, Hu HM, Wang Z, et al. RNA-seq of 272 gliomas revealed a novel, recurrent PTPRZ1-MET fusion transcript in secondary glioblastomas. Genome research. 2014; 24:1765-1773.

28. Comprehensive molecular characterization of urothelial bladder carcinoma. Nature. 2014; 507:315-322.

29. Guo G, Sun X, Chen C, Wu S, Huang P, Li Z, Dean M, Huang Y, Jia W, Zhou Q, Tang A, Yang Z, Li X, Song $\mathrm{P}$, Zhao X, Ye R, et al. Whole-genome and whole-exome sequencing of bladder cancer identifies frequent alterations in genes involved in sister chromatid cohesion and segregation. Nature genetics. 2013; 45:1459-1463.

30. Capelletti M, Dodge ME, Ercan D, Hammerman PS, Park SI, Kim J, Sasaki H, Jablons DM, Lipson D, Young L, Stephens PJ, Miller VA, Lindeman NI, Munir KJ, Richards WG and Janne PA. Identification of recurrent FGFR3TACC3 fusion oncogenes from lung adenocarcinoma. Clin Cancer Res. 2014; 20:6551-6558.

31. Wang R, Wang L, Li Y, Hu H, Shen L, Shen X, Pan Y, Ye T, Zhang Y, Luo X, Zhang Y, Pan B, Li B, Li H, Zhang J, Pao W, et al. FGFR1/3 tyrosine kinase fusions define a unique molecular subtype of non-small cell lung cancer. Clin Cancer Res. 2014; 20:4107-4114.

32. Kim Y, Hammerman PS, Kim J, Yoon JA, Lee Y, Sun JM, Wilkerson MD, Pedamallu CS, Cibulskis K, Yoo YK, Lawrence MS, Stojanov P, Carter SL, McKenna A, Stewart C, Sivachenko AY, et al. Integrative and comparative genomic analysis of lung squamous cell carcinomas in East Asian patients. J Clin Oncol. 2014; 32:121-128.

33. Majewski IJ, Mittempergher L, Davidson NM, Bosma A, Willems SM, Horlings HM, de Rink I, Greger L, Hooijer GK, Peters D, Nederlof PM, Hofland I, de Jong J, Wesseling J, Kluin RJ, Brugman W, et al. Identification of recurrent FGFR3 fusion genes in lung cancer through kinome-centred RNA sequencing. The Journal of pathology. 2013; 230:270276.

34. Comprehensive molecular profiling of lung adenocarcinoma. Nature. 2014; 511:543-550.

35. Comprehensive genomic characterization of squamous cell lung cancers. Nature. 2012; 489:519-525.

36. Carneiro BA, Elvin JA, Kamath SD, Ali SM, Paintal 
AS, Restrepo A, Berry E, Giles FJ and Johnson ML. FGFR3-TACC3: A novel gene fusion in cervical cancer. Gynecologic oncology reports. 2015; 13:53-56.

37. Xiang L, Li J, Jiang W, Shen X, Yang W, Wu X and Yang H. Comprehensive analysis of targetable oncogenic mutations in chinese cervical cancers. Oncotarget. 2015; 6:4968-4975. doi: 10.18632/oncotarget.3212.

38. Comprehensive genomic characterization of head and neck squamous cell carcinomas. Nature. 2015; 517:576-582.

39. Parish A, Schwaederle M, Daniels G, Piccioni D, Fanta P, Schwab R, Shimabukuro K, Parker BA, Helsten T and Kurzrock R. Fibroblast growth factor family aberrations in cancers: clinical and molecular characteristics. Cell cycle (Georgetown, Tex). 2015; 14:2121-2128.

40. Sharma P, Shen Y, Wen S, Yamada S, Jungbluth AA, Gnjatic S, Bajorin DF, Reuter VE, Herr H, Old LJ and Sato E. CD8 tumor-infiltrating lymphocytes are predictive of survival in muscle-invasive urothelial carcinoma. Proceedings of the National Academy of Sciences of the
United States of America. 2007; 104:3967-3972.

41. Sweis RF SS, Gajewski T. Molecular drivers of the non-T cell-inflamed tumor microenvironment in urothelial bladder cancer. J Clin Oncol 2015;33:abstract 4511.

42. Spranger S, Bao R and Gajewski TF. Melanoma-intrinsic beta-catenin signalling prevents anti-tumour immunity. Nature. 2015; 523:231-235. 